\title{
Adherance towards Antihy[ertensive medications among Patients attending the Family Practice Clinics in Ismailia
}

Moustafa M Ahmed ${ }^{* 1}$, Wael A Zeid ${ }^{2}$, Madeha M Hamed ${ }^{2}$, Mosleh A Ismail ${ }^{2}$

${ }^{1}$ Department of Family Medicine, South Valley University.

${ }^{2}$ Department of Family Medicine, Suez Canal University. ${ }^{1}$

\begin{abstract}
:
Background: Hypertension is a major health problem in Egypt with a prevalence rate of $26.3 \%$. Only $23.9 \%$ receive treatment but the hypertension is controlled in only $8 \%$. Low adherence remains a public health challenge as it requires a high health care cost. Identifying adherence barriers to antihypertensive medications may help to identify interventions to improve blood pressure control. Objectives: To assess levels of adherence and its barriers, and to identify the relation between adherence and blood pressure control. Methods: A crosssectional study was conducted on 90 hypertensive patients attending the family practice clinic, Suez Canal University hospital in Ismailia city using a structured questionnaire including socio-demographic scale, Morisky 8-Item Medication Adherence Questionnaire, and Adherence Barriers Questionnaire (ABQ). Blood pressure was also measured. Results: Less than two thirds $(61.1 \%)$ of the participants have a low level of adherence. There is a significant association between the level of adherence to anti-hypertensive medications and blood pressure control $(\mathrm{p}<0.01)$. Conclusion: The study confirmed the association between adherence, patients' age, occupation, type of healthcare facilities, crowding index, socioeconomic status, and blood pressure control.
\end{abstract}

Keywords: Adherence, Blood pressure control, Hypertension

Introduction: Hypertension is considered as an overwhelming global challenge, which is considered the third cause of disability-adjusted life-years responsible. ${ }^{(1)}$ The prevalence of hypertension in Egypt is 26.3\%. Although 23.9\% of hypertensive individuals receive pharmacological treatment (2), HTN control is very low in Egypt. (3) World Health Organization (WHO) describes poor adherence as the most important cause of uncontrolled blood pressure. ${ }^{(4)}$

Poor adherence is associated with decreased medication effectiveness, substantial worsening of diseases, higher healthcare costs, and increased mortality rates. ${ }^{(5)}$ Many tools have been used to assess adherence in clinical research, including self-reporting, electronic monitoring, prescription refills, pill counting, direct observable behavior, drug levels in biological fluids. ${ }^{(6)}$ However, no single measure of medication adherence is appropriate for all settings or outcomes. (7)

Uncontrolled blood pressure increases the risk of cardiovascular morbidity and mortality. ${ }^{(4)}$ Identifying non-adherent patients in outpatient settings and understanding barriers of adherence to antihypertensive medication may help to identify interventions which may elevate level of adherence and improve outcomes. ${ }^{(8)}$ Objectives: To assess levels of adherence and its barriers, and to identify the relation between adherence and blood pressure control.

*Corresponding author: E-mail: dr.moustafa90@gmail.com 


\section{Ahmed et al: Adherence to antihypertensive medication}

Subjects and Methods: A cross sectional study, conducted on 90 hypertensive patients attending family practice clinic at Suez Canal university hospital. The participants with primary hypertension were recruited by using non-probability consecutive sampling from December 2017 to March 2018, after excluding those with target organ damage or women with hypertension during pregnancy. The participants were interviewed using a validated and reliable questionnaire, which contains three sections: 1) the socioeconomic scale (SES), which assessed seven domains; Education, occupation, family, family possessions, economic, home sanitation and healthcare domains, with a total score of 84 .

It was classified into very low, low, middle and high levels depending on the quartiles of the score. ${ }^{(9)}$ 2) assessment of adherence level by using 8-items Morisky questionnaire. Response categories were yes $($ score $=1) /$ no $($ score $=0)$ for the first seven items, while the last one has a 5-point Likert response (scores $\mathrm{A}=0$ and $\mathrm{B}-\mathrm{E}=1$ ). The total adherence level was categorized according to the scoring system as low ( >2 ), medium $(1-2)$ and high $(=0){ }^{(10)}$ 3) adherence barriers questionnaire (ABQ). It is a total of 16 items addressing intentional, unintentional, medication- related and healthcare system-related barriers. These items represent coping behavior, attitude, cost, depression, dementia, forgetfulness, needing help, and fear or experience of side effects. Each item was formulated as a 4-point Likert scale. ABQ has a high internal consistency (Cronbach' $\mathrm{s}$ alpha $=0.820) .{ }^{(11)}$ Blood pressure was also measured after the interview, to assess blood pressure control

Data management: The statistical package (SPSS 21.0.0) was used for analysis of data. Data was presented using graphs. Descriptive tables in the form of frequencies and percentages were used for qualitative variables, and means and standard deviations for quantitative variables. Qualitative variables were compared using Chi-square test, whenever the expected values in more than $20 \%$ of the cells is less than 5, Fisher's exact test was used instead. Quantitative variables were compared by using t-test. Logistic regression analysis was used for identifying the predictors of outcome variables (adherence, BP control). P-value $<0.05$ was considered statistically significant.

Ethical Considerations:All patient information and data were highly confidential. All the procedures of the study were approved by the family medicine department and the local ethics committee. Informed consent was taken from the patients to participate in the study, after clarifying the aim of the study.

Results:The participants' mean age was $53.44 \pm 12.24$ years. About three quarters $(74.4 \%)$ of them were females and $86.7 \%$ came from rural areas. Crowding index showed that about half 


\section{Ahmed et al: Adherence to antihypertensive medication}

of the sample had less than one person in each room. Furthermore, $57.8 \%$ and $17.8 \%$ of the participants lived in a low and very low socioeconomic level, respectively (Table 1).Low adherence to medications formed $61.1 \%$ of the sample, while medium adherence formed $35.6 \%$, whereas high adherence was only $3.3 \%$ (Figure 1).

Barriers were classified into 4 categories; the intentional barrier, health care systemrelated barrier, the unintentional barriers and medication related barriers. The most common barriers included; cost (74\%), depression (68\%), dementia (65\%), need help (61\%), forgetfulness $(55 \%)$, fear from side effect $(45 \%)$ and experience from side effect barrier (33\%) (Figure 2). The study identified that adherence was significantly associated with age ( $\mathrm{p}=0.014)$, occupation $(\mathrm{p}=0.03)$, health care facilities $(\mathrm{p}=0.028)$, crowding index $(\mathrm{p}=0.01)$ and socioeconomic level ( $\mathrm{p}=0.034)$ (Table 2).

Finally, there was significant association between level of adherence to antihypertensive medications and blood pressure control ( $\mathrm{p}<0.01)$ (Table 3). Logistic regression of adherence showed that best-fitting predictors of adherence level were blood pressure control and crowding index. Adherence levels were low and significantly associated with blood pressure control (Table 4).

Discussion: Globally, the prevalence of non-adherence to antihypertensive medications among hypertensive patients has been estimated to be $45.2 \%$. However, this estimate has been even higher among African patients, with a non-adherence rate as high as $62.5 \%$. Furthermore, the prevalence of non-adherence is estimated to increase by $30 \%$ by the year 2025 . $^{(12)}$ Similarly, the study identified that $61 \%$ of our patients were poorly adherent to their medications. This could be explained by the high predominance of patients with low and very low socio-economic status along with the high cost of long-term medications.

Regarding the barriers to medication adherence, four categories were identified; intentional barriers, unintentional barriers, medication-related barriers, and healthcare systemrelated barriers. The most frequent barriers within the four categories reported by our patients were: struggling with depression and/or dementia, forgetfulness, their continuous need for help, and the burden of costly treatment. Previous studies have consistently identified higher co-payment, side effects of medications; especially sexual dysfunction, and a poor patientprovider relationship as barriers affecting the adherence to antihypertensive medication. ${ }^{(13)}$

The study identified that the age was significantly associated with the level of adherence to antihypertensive medications, with a high level of adherence observed specifically among older patients $(\mathrm{p}=0.014)$. This finding may be explained by the better awareness of the 


\section{Ahmed et al: Adherence to antihypertensive medication}

disease or even the presence of complications. Hyre et al (2007) assessed the level of adherence in 295 patients and reported that adults younger than 60 years were more likely to be less adherent when compared with older patients. ${ }^{(14)}$ Kang et al (2014) conduct a study on a larger population (2,445 hypertensive patients) and found that older patients tend to have a better medication adherence, which is consistent with this finding. ${ }^{(15)}$ In contrary, a more recent study conducted on 189 hypertensive patients found that age was not significantly associated with the level of adherence to antihypertensive medications. ${ }^{(16)}$

In relation to the blood pressure control, the study identified that those with crowding index of one or less person/room were more controlled than those with a crowding index of more than one person per room. The higher socioeconomic level with less crowding index may explain this finding. However, no significant difference was observed between controlled and uncontrolled patients in terms of other socio-demographic characteristics. This finding is consistent with Kang et al (2014) who reported that age, gender, educational level, employment status, and monthly household income didn't affect blood pressure control significantly. ${ }^{(15)}$

The study identified a strong association between the level of adherence to antihypertensive medications and blood pressure control $(<0.01)$. A study conducted on 840 hypertensive patients found that only $43 \%$ of high-adherence patients attained their target blood pressure goal compared to $33 \%$ to $34 \%$ of patients with medium or low adherence to antihypertensive mono-therapy. ${ }^{(17)}$

Limitations of this study: The current study had some limitations. The study couldn't evaluate lifestyle modifications, as a factor affecting the adherence to antihypertensive medications and blood pressure control. Furthermore, the study did not assess the effect of co-morbidities on patients' adherence and blood pressure control. This can be argued by the complexity of the lifestyle modifications and co-morbidities in improving adherence and control of blood pressure.

Conclusion: The current study evaluated the factors associated with medication adherence and blood pressure control and confirmed the association between antihypertensive medications adherence, patients' age, occupation, type of healthcare facilities, crowding index, socio-economic status, and blood pressure control.

Acknowledgment: The authors would like to thank the participants and the clinic staff for their help to accomplish this work. 


\section{Ahmed et al: Adherence to antihypertensive medication}

Fund: No fund was received.

Conflict of interest: There is no conflict of interest.

\section{References:}

1. World Health Organization (WHO). Global health risks: Mortality and burden of disease attributable to selected major risks. Geneva, 2009; P.11.

2. Ibrahim, M., Rizk, H., Appel, L., El Aroussy, W., Helmy, S., Sharaf, Y., et al. Hypertension prevalence, awareness, treatment, and control in Egypt. Results from the Egyptian National Hypertension Project (NHP). NHP Investigative Team. J. hypertension, Dec, 1995; 26 (6 Pt 1):886-90.

3. Chow, C., Teo, K., Rangarajan, S., Islam, S., Gupta, R., Avezum, A., et al. Prevalence, awareness, treatment, and control of hypertension in rural and urban communities in high, middle-, and low-income countries. JAMA., 2013; 310 (9) 959-68.

4. World Health Organization (WHO). Hypertension in Adherence to Long-Term TherapiesEvidence for Action. 2003; p 107.

5. Sokol, M., McGuigan, K., Verbrugge, R., Epstein, R. Impact of medication adherence on hospitalization risk and healthcare cost. Med Care. Jun, 2005;43(6):521-30.

6. Duong, M., Piroth, L., Grappin, M., Forte, F., Peytavin, G., Buisson, M., et al. Evaluation of the Patients on antiretroviral regimens. HIV Clin T rials, 2001; 2(2): 128 135.

7. Vitolins, M., Rand, C., Rapp, S., Ribisl, P. and Sevick, M. Measuring adherence to behavioral and medical interventions. Control Clin Trials 1, 2000; 188S-194S.

8. Krousel-Wood, M., Muntner, P., Islam, T., Morisky, D., Webber, L. Barriers to and Determinants of Medication Adherence in Hypertension Management: Perspective of the Cohort Study of Medication Adherence among Older Adults (CoSMO). Med Clin North Am, 2009; 93(3), 753-769.

9. El-Gilany, A., El-Wehady, A., El-Wasify, M. Updating and validation of socioeconomic status scale for health research in Egypt, EMHJ, 2012; 18( 9):962-8.

10. Morisky, D., Green, L., Levine, D. Concurrent and predictive validity of self-reported measure of medication adherence. Med. Care., 1986; 24:67-74.

11. Sabrina, M., Thomas, K., Thomas, W. Validation of the Adherence Barriers Questionnaire - an instrument for identifying potential risk factors associated with medication-related non-adherence. BMC Health Services Research, 2015; 15:153 


\section{Ahmed et al: Adherence to antihypertensive medication}

12. Abegaz, T. , Shehab, A., Gebreyohannes, E., Bhagavathula, A., and Elnour, A. Nonadherence to antihypertensive drugs: A systematic review and meta-analysis. Medicine, 2017; 96(4), e5641.

13. Laan, D. Van Der, Elders, P., Boons, C., Beckeringh, J., Nijpels, G., et al. Factors associated with antihypertensive medication non-adherence : a systematic review. J Hum Hypertens., 2017; 31(11), 687-694.

14. Hyre, A., Krousel-Wood, M., Muntner, P., Kawasaki, L., DeSalvo, K. Prevalence and predictors of poor antihypertensive medication adherence in an urban health clinic setting. J Clin Hypertens, 2007; 9(3), 179-186.

15. Kang, C., Tsang, P., Li, W., Wang, H., Liu, K., Griffiths, S., et al. Determinants of medication adherence and blood pressure control among hypertensive patients in Hong Kong: A cross-sectional study. Int J Cardiol, 2014; 182, 250-257.

16. Balasubramanian, A., Nair, S., Rakesh, P., Leelamoni, K. Adherence to treatment among hypertensives of rural Kerala, India. J Family Med Prim Care, 2018; 7(1), 64-69.

17. Bramley, T., Nightengale, B., Frech-Tamas, F., Gerbino, P. Relationship of Blood Pressure Control to Adherence With Antihypertensive Monotherapy in 13 Managed Care Organizations. J Manag Care Pharm, 2006;12(3):239-45. 
Ahmed et al: Adherence to antihypertensive medication

Table (1): Socio demographic characteristics of the studied population $(n=90)$

\begin{tabular}{|c|c|}
\hline Variables & $\mathbf{N}(\%)$ \\
\hline Age, mean $( \pm$ SD) & $53.44( \pm 12.24)$ \\
\hline \multicolumn{2}{|l|}{ Gender } \\
\hline - Male & $23(25.6)$ \\
\hline - Female & $67(74.4)$ \\
\hline \multicolumn{2}{|l|}{ Residency } \\
\hline - $\quad$ Rural & $78(86.7)$ \\
\hline - Urban & $2(2.2)$ \\
\hline - Urban(Slum)* & $10(11.1)$ \\
\hline \multicolumn{2}{|l|}{ Crowding index } \\
\hline - $\leq$ one person /room & $45(50)$ \\
\hline - $>$ one person /room & $45(50)$ \\
\hline \multicolumn{2}{|l|}{ Socio-economic level } \\
\hline - Very low & $16(17.8)$ \\
\hline - Low & $52(57.8)$ \\
\hline - $\quad$ Medium & $18(20)$ \\
\hline - High & $4(4.4)$ \\
\hline
\end{tabular}

Data are presented as number (\%) or mean and SD.

*Urban slums are settlements, neighborhoods, or city regions that cannot provide the basic living conditions necessary for its inhabitants.

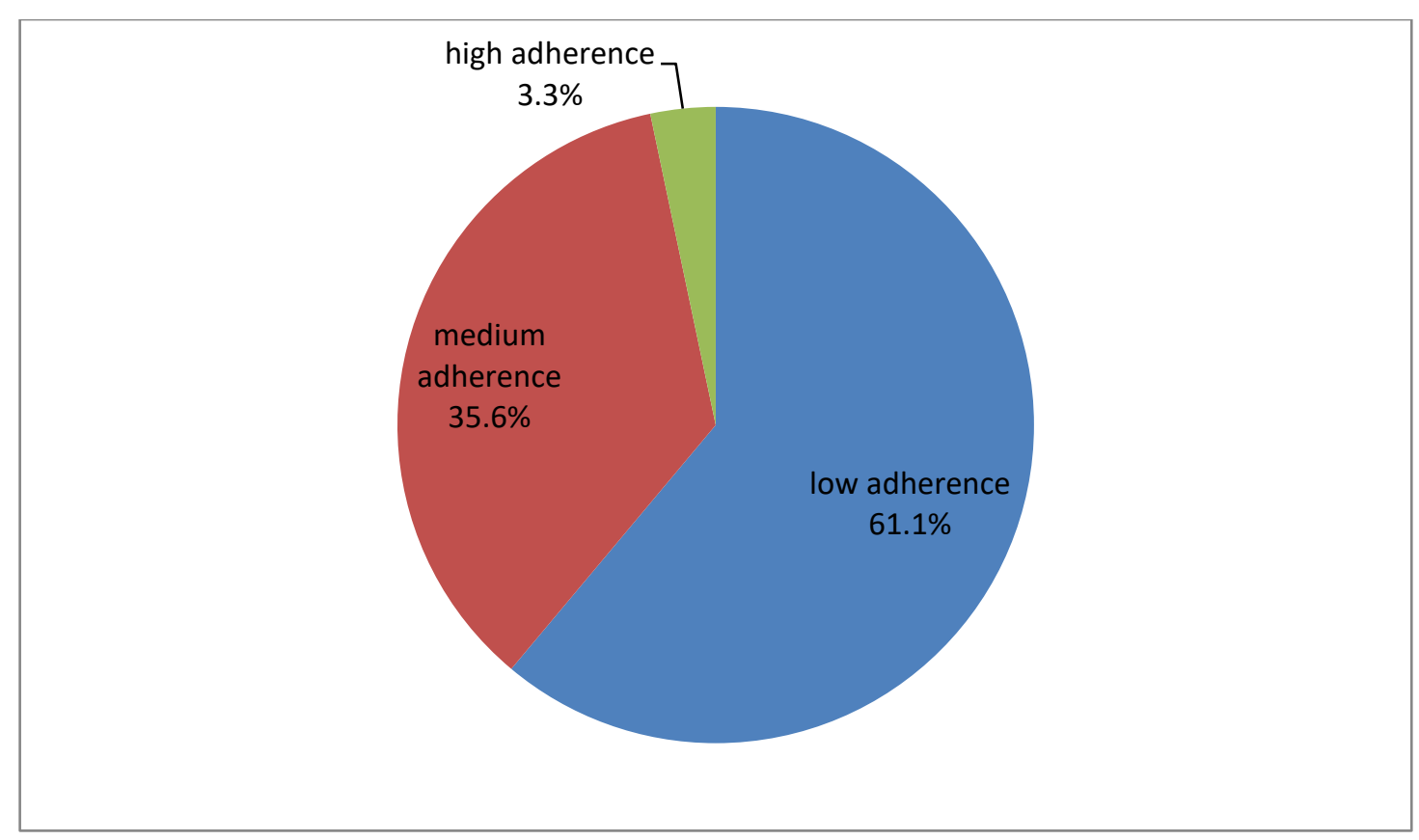

Figure (1): Level of adherence to anti-hypertensive medications among the studied sample 
Ahmed et al: Adherence to antihypertensive medication

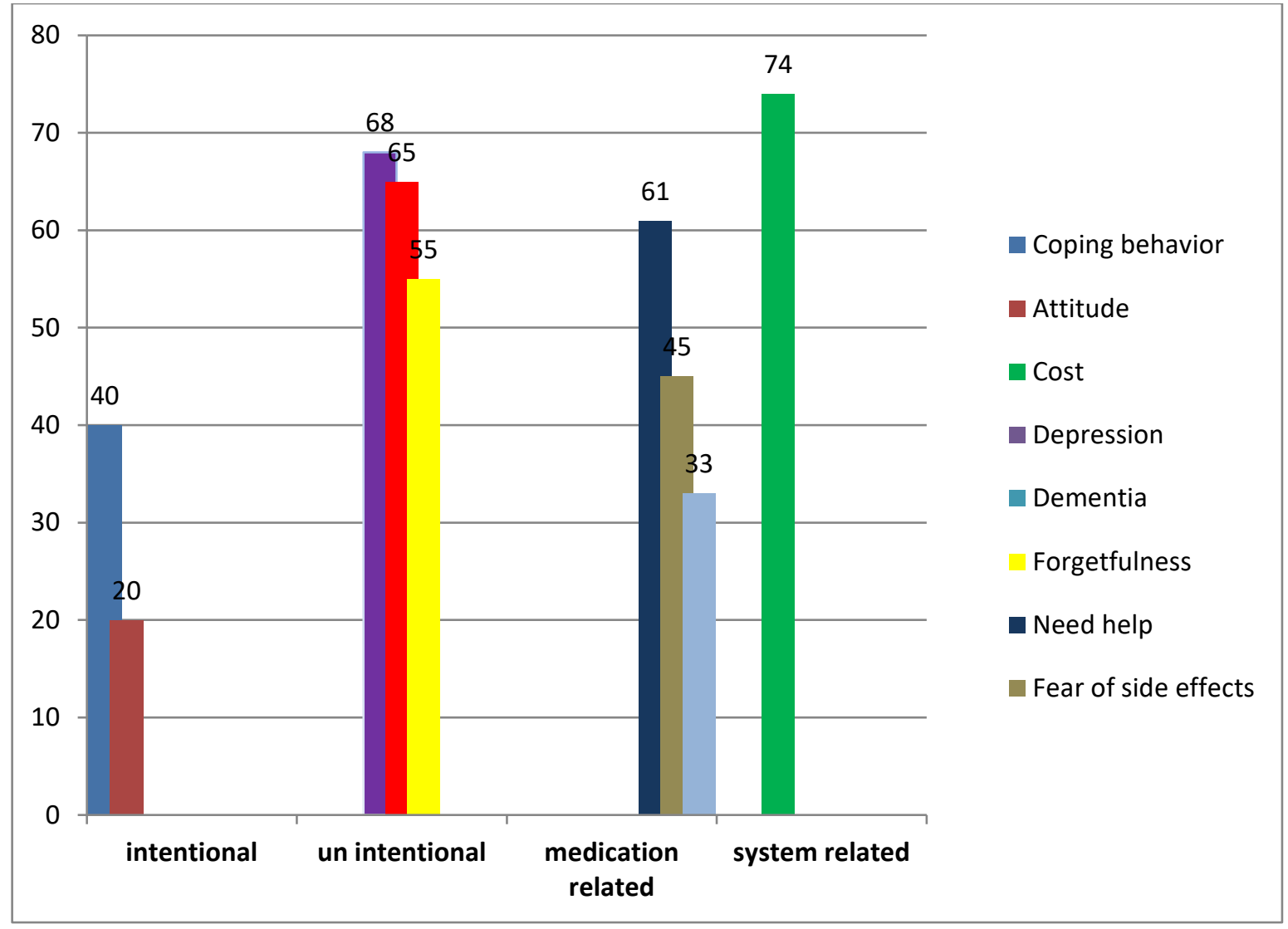

Figure (2): Causes of non-adherence 
Ahmed et al: Adherence to antihypertensive medication

Table (2): Relationship between socio demographic characteristics and adherence to anti-hypertensive medications:

\begin{tabular}{|c|c|c|c|c|c|}
\hline \multirow[t]{2}{*}{ Variables } & \multicolumn{3}{|c|}{ Adherence level } & \multirow[t]{2}{*}{ Value } & \multirow[t]{2}{*}{ p-value } \\
\hline & $\begin{array}{l}\text { low } \\
n=55\end{array}$ & $\begin{array}{l}\text { medium } \\
n=32\end{array}$ & $\begin{array}{l}\text { High } \\
n=3\end{array}$ & & \\
\hline Age, mean (SD) & $\begin{array}{l}51.71 \\
(10.95)\end{array}$ & $\begin{array}{l}54.87 \\
(13.67)\end{array}$ & $70(0)$ & 8.528 & $0.014 * \mathrm{a}$ \\
\hline \multicolumn{6}{|l|}{ Gender } \\
\hline - Male & $14(25.5)$ & $9(28.1)$ & - & \multirow[t]{2}{*}{0.686} & \multirow[t]{2}{*}{$0.833^{\mathrm{b}}$} \\
\hline - Female & $41(74.5)$ & $23(71.9)$ & $3(100)$ & & \\
\hline \multicolumn{6}{|l|}{ Residency } \\
\hline - Rural & $46(83.6)$ & $29(90.6)$ & $3(100)$ & \multirow[t]{3}{*}{2.91} & \multirow[t]{3}{*}{$0.613^{\mathrm{b}}$} \\
\hline - Urban (Slum) & $8(14.5)$ & $2(6.3)$ & - & & \\
\hline - Urban & $1(1.8)$ & $1(3.1)$ & - & & \\
\hline \multicolumn{6}{|l|}{ Occupation } \\
\hline - Housewife & $33(60)$ & $30(93.8)$ & $3(100)$ & \multirow[t]{5}{*}{15.353} & \multirow[t]{5}{*}{$\mathbf{0 . 0 3} * \mathrm{~b}$} \\
\hline - Unskilled manual work & $6(10.9)$ & $1(3.1)$ & - & & \\
\hline - $\quad$ Skilled manual work & $3(5.5)$ & - & - & & \\
\hline - Trades/business & $2(3.6)$ & $1(3.1)$ & - & & \\
\hline - Semi-professional/clerk & $11(20)$ & - & - & & \\
\hline \multicolumn{6}{|l|}{ Health Care facilities } \\
\hline - More than one source & $18(32.7)$ & $18(56.3)$ & - & \multirow[t]{4}{*}{12.07} & \multirow[t]{4}{*}{$\mathbf{0 . 0 2 8} * \mathrm{~b}$} \\
\hline - Free governmental health services & $15(27.3)$ & $9(28.1)$ & $3(100)$ & & \\
\hline - Health insurance & $4(7.3)$ & - & - & & \\
\hline - $\quad$ Private health facilities & $18(32.7)$ & $5(15.6)$ & - & & \\
\hline \multicolumn{6}{|l|}{ Crowding index } \\
\hline - $\leq$ one person /room & $16(29.1)$ & $27(84.4)$ & $2(66.7)$ & \multirow[t]{2}{*}{26.16} & \multirow[t]{2}{*}{$<0.01 * \mathrm{~b}$} \\
\hline - $>$ one person /room & $39(70.9)$ & $5(15.6)$ & $1(33.3)$ & & \\
\hline \multicolumn{6}{|l|}{ Socio-economic level } \\
\hline - Very low & $11(20)$ & $3(9.4)$ & $2(66.7)$ & \multirow[t]{4}{*}{11.96} & \multirow[t]{4}{*}{$0.034 * b$} \\
\hline - Low & $26(47.3)$ & $25(78.1)$ & $1(33.3)$ & & \\
\hline - Medium & $15(27.3)$ & $3(9.4)$ & - & & \\
\hline - High & $3(5.5)$ & $1(3.1)$ & - & & \\
\hline
\end{tabular}

${ }^{a} p$-value are based on Kruskal-Wallis Test. Statistical significance $<0.05$

${ }^{\mathrm{b}} \mathrm{p}$-value are based on Chi-Square or Fisher's Exact Test as appropriate.

*Statistical significance $<0.05$ 
Ahmed et al: Adherence to antihypertensive medication

Table (3): Relationship between adherence level and blood pressure control:

\begin{tabular}{|c|l|l|l|l|}
\hline Adherence level & \multicolumn{2}{|l|}{ Blood pressure control } & \multirow{2}{*}{ value } & \multirow{2}{*}{ p-value } \\
\cline { 2 - 4 } & controlled & Not controlled & & \\
\cline { 2 - 3 } - Low & & & \\
\hline - Medium & $18(40.9)$ & $37(80.4)$ & 15.05 & $<0.01^{*}$ \\
\hline High & $24(54.5)$ & $8(17.4)$ & \\
\hline
\end{tabular}

* P-value are based on Fisher's-exact test as appropriate. Statistical significance $<0.05$. 
Ahmed et al: Adherence to antihypertensive medication

Table (4): Logistic regression analysis of adherence level among patients.

\begin{tabular}{|c|c|c|c|}
\hline Variables & $\beta(\mathbf{S E})$ & OR $(95 \% \mathrm{CI})$ & p-value \\
\hline Constant & $-4.56(2.23)$ & & 0.01 \\
\hline Age & $0.002(0.027)$ & $1.002(0.949-1.057)$ & 0.951 \\
\hline \multicolumn{4}{|l|}{ Blood pressure control } \\
\hline - Controlled VS uncontrolled & $2.48(0.718)$ & $12.038(2.949-49.142)$ & 0.001* \\
\hline \multicolumn{4}{|l|}{ Crowding index } \\
\hline - $\leq$ one VS $>1$ person /room & $3.176(0.751)$ & $23.953(5.498-104.357)$ & $<0.01 *$ \\
\hline \multicolumn{4}{|l|}{ Socioeconomic level } \\
\hline - Very low VS High & $-0.728(1.848)$ & $0.483(0.013-18.077)$ & 0.694 \\
\hline - Low VS High & $2.075(1.749)$ & $7.962(0.258-245.552)$ & 0.236 \\
\hline - Medium VS High & $-0.928(1.82)$ & $0.395(0.011-14.067)$ & 0.611 \\
\hline
\end{tabular}

* Statistical significance $<0.05$.

Omnibus test for Model fit (p-value $<0.001) \chi^{2}(3)=17.719, \mathrm{P}<0.001$

Model summary: -2 Log likelihood= 147.605; Cox \& Snell $R^{2}=0.111 ;$ Nagelkerke $R^{2}=0.167$ 
Ahmed et al: Adherence to antihypertensive medication

\section{الملخص العربى - ابى}

الالتزام بالأدوية الخافضة للضغط بين مرضى الضغط المرتفع المترددين على عيادة طب الأسرة بالاسماعيلية

مصطفى محمود أحمد- و ائل أحمد زيد ـ مديحة محمد حامد ـ مصلح عبدالرحمن اسماعيل

الخلفية:. ان معدل انتشار ارتفاع ضغط الدم في مصر هو 26.3٪ و على الرغم من أن 23.9٪ من الأفر اد الذين يعانون من ارتفاع ضغط الدم يتلقون العلاج الدوائي ، فإن نسب السيطرة على الضغط المرتفع منخفضة جدا في مصر . يعد عدم الالتز ام بتتاول الدواء الخافض لضغط الدم من اهم اسباب ضعف السيطرة على ضغط الدم. الهلف هو تقييم مدى التزام مرضى لفى

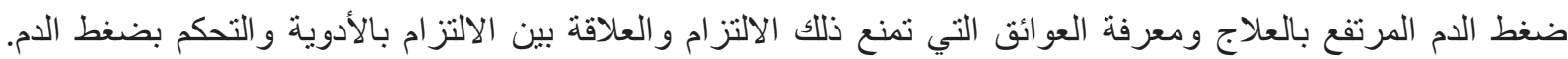
الطريقة: دراسة مقطعية مستعرضة على 90 من مرضى ضغط الدم المرتفع المترددين على عيادة طب الأسرة باستخدام نموذج استبيان لدر اسة الحالة الاجتماعية والاقتصادية للمشاركين بالبحث, تقييم مدى التز ام مرضى الضغط المرتفع بالأدوية

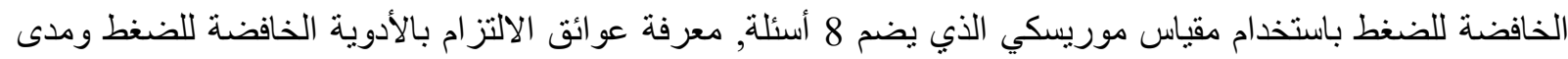

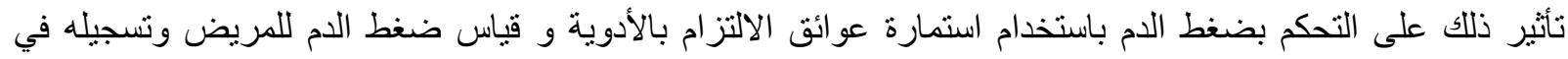

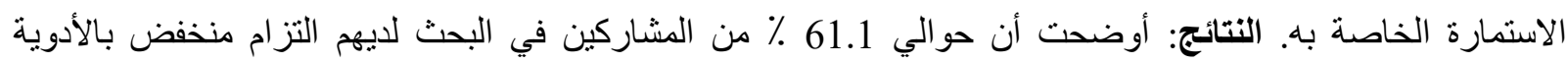
الخافضة للضغط ، و شكلت نسبة الالتز ام المتوسط حوالي 35.6 ٪ ، في حين كان الالتز ام العالي بنسبة 3.3 ٪ فقط. تنقسم عو ائق الالتزام بالأدوية الى أربعة أقسام: عوائق بقصد من المريض, عوائق بغير قصد, عوائق متعلقة بالأدوية, وعوائق متعلقة بالنظام الصحي ومقدم الخدمة الصحية. كانت أكبر اسباب عدم الالتزام هي الاكتئاب (68 \%) و الخرف (65 \%). يليه النسيان الذي يمثل نسبة 55٪ من المرضى. في حين 42 ٪ من المرضى كان سبب عدم الالنز ام هو الحذر. و أظهرت النتائج

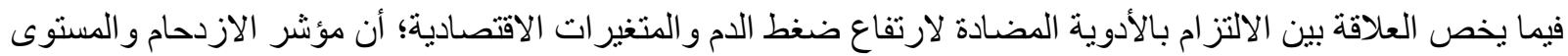
الاجتماعي و الاقتصادي يؤثران بشكل ملحوظ في مستوى الالنزام بالأدوية المضادة لارتفاع ضغط الدم. كما أوضحت الدراسة أن هناك ارتباط كبير بين مدى الالتز ام بالأدوية المضادة لارتفاع ضغط الدام و التحكم في ضغط الدام .الخلاصة:

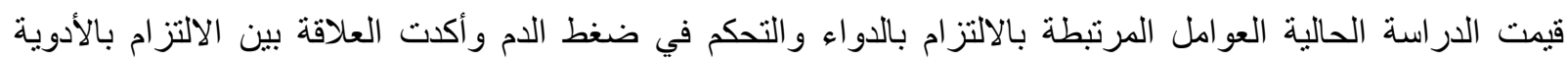

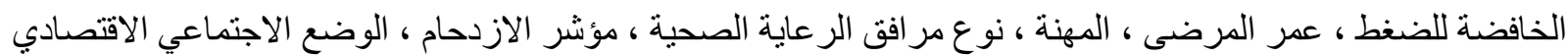
، و و التحكم في ضغط الدم. 